\title{
Monografico
}

DOI: http://dx.doi.org/10.25115/eea.v39i1.4268

\section{Gen Y and Gen Z Communication Style}

\author{
HUMAIRA RASLIE*, SU-HIE TING \\ Faculty of Language and Communication, UNIVERSITI MALAYSIA SARAWAK, MALAYSIA. \\ *E-mail: rhumaira@unimas.my
}

\begin{abstract}
Communication style plays a crucial role in managing the multigenerational ecosystem of the present world. This study examined the communication style of Gen $Y$ and Gen Z. The participants were 311 youth (Gen Y, 68; Gen Z, 243). The questionnaire on communication style was developed based on Hartman and McCambridge (2011). The online survey was conducted from 6 April 2020 to 11 May 2020 by distributing the questionnaire link to people who were in the Gen $Y$ and Gen $Z$ age groups. The results showed that both groups were similar in their general characteristics, which included preferences for group-work, affirmation, clear rules, and for their opinions to be valued. They liked face-to-face communication, and using visuals for online communication. There were significant differences in some of their study and work habits, that is, the Gen $\mathrm{Y}$ are better than Gen $\mathrm{Z}$ at analysing information obtained from the Internet, and handling a lot of work at one time, whereas Gen Z expected more instantaneous feedback than Gen Y. As for communication style, they were amiable communicators who were low on assertiveness, prioritised relationship over task in task completion, and had a slow-paced communication style. The results showed that Gen $Y$ and Gen $Z$ had some style-typing ability, whereby they compared their communication style with their peers. More practised style-flexing, as in fitting their communication to the target group but Gen $Y$ had a stronger information-focus. Their demographic background (gender, ethnic group, socio-economic status) did not influence their communication style, indicating the stronger influence of their generational cohort. The study suggests that employers who require goal-oriented communication need to make their expectations clear to Gen $Y$ and Gen $Z$ employees.
\end{abstract}

Keywords: Gen Y, Gen Z, communication style, assertive, responsive, task completion

JEL Classification: C1, L2

Recibido: 1 de Diciembre de 2020

Aceptado: 14 de Diciembre 2020 


\section{Introduction}

Multigenerational studies have shown that generational cohorts are more than just demographic information (Ismail, 2016). In this paper, Dimock's (2019) definition of the age range for Generation $Y$ or millennials (Gen $Y$ henceforth) and Generation $Z$ (Gen $Z$ henceforth) is used. Gen $Y$ are born between 1981 and 1996, and they are aged 24-39 (in the year 2020). Gen Z are born in 1997 and onwards, and are aged 23 and below (in the year 2020). Studies on Gen Y gained momentum when businesses realise that this cohort has unconventional workplace expectations that affect managerial practices, and the overall workplace culture (Abdul Malek \& Jaguli, 2018; Said et al., 2020; Smith \& Nichols, 2015). In Malaysia, Gen $Y$ accounts for more than $40 \%$ of the workforce (Jalil et al., 2015).

Employee retention became a complex endeavour across all industries, propelling research to identify factors that would ensure Gen Y's long-term loyalty to their respective hiring organisations (Mohd Soieb, Othman, \& D'Silva, 2015; Naim \& Lenka, 2017; Stewart et al., 2017). In Malaysia for instance, generational differences concerning workplace expectation, job satisfaction and leadership style preference contribute to the deficit of talents in the labour force (Ahmad \& Ibrahim, 2016; Islam et al., 2011). Koh (2018) found that in the Malaysian food industry, Gen Y employees would stay in a job if they have job satisfaction, good leadership and good compensation. Polytechnic graduates stay at their job because of the money and the enjoyable work (Yeap et al., 2018). What is known about communication style is that Gen Y employees are eager to engage with their superiors (Soieb, Othman, \& D'Silva, 2015) and seek constant coaching and feedback from their mentors (Stewart et al., 2017). They respond well to open, transparent and frequent communication, particularly through text-messaging and social media (Abdul Malek \& Jaguli, 2018). However, Abdul Malek and Jaguli's (2018) study only involved female leaders giving their views on Gen Y employees. Andi (2018) offers Malaysian Gen Y's perspective on leadership style. They gravitate towards transformational leadership, meaning that they expect their leaders to communicate the organisational goals clearly and consistently, and to work with them to achieve the goals. Andi (2018) also found that the millennials expect their leaders to talk with them about their motivation and problems. Transformational leaders need to have a high level of knowledge and skills in communication to yield positive results (Holt et al., 2012). Gen Y employees also like a customised and informal approach in workplace communication (see also Myers \& Sadaghiani, 2010; Smith \& Nichols, 2015). These studies focused on employers' and Gen Y's perspectives on the content, frequency and medium of communication but not on communication style.

In comparison to Gen $Y$, there is less research on Gen $Z$ because they have just begun to enter the workforce. In a few years, the workforce is going to consist of four generations, with the latest addition being the Gen Z employees (King et al., 2019; Said et al., 2020). The available findings on Gen Z is largely on their traits (Raslie et al., 2016; Törőcsik et al., 2014), with many academic papers repeating descriptions of Gen Z (Said et al., 2020; Schwieger \& Ladwig, 2018; Singh \& Dangmei, 2016; Turner, 2015). Other researchers have written about Gen Z students (Rickes, 2016; Seemiller \& Grace, 2016; Sriprom et al., 2019). For instance, Sriprom et al. (2019) found that Gen Z university students view themselves as high on the agreeableness in the Big Five personality model, and caution that individuals with this trait may be erratic and insecure. They avoid group conflict and competitiveness in group work, and may have difficulties performing individual tasks and making decisions. Campiere (2019) found that Gen Z employees like to get daily feedback from their superiors, and are willing to share information, but like to communicate using emoticons, gifs and acronyms which may be challenging to older generation. Our exhaustive literature search revealed that no studies have been conducted on the communication style of Gen Z.

Malaysia is experiencing is talent deficit in labour force, with Gen $Y$ and Gen $Z$ not displaying job loyalty like the Baby Boomers and Gen X (Ahmad \& Ibrahim, 2016; Islam et al., 2011). One area that can 
be improved to retain talent is communication because Gen $\mathrm{Y}$ and Gen $\mathrm{Z}$ like transparent communication and constant feedback (Abdul Malek \& Jaguli, 2018; Andi, 2018; Campiere, 2019; Soieb et al., 2015; Stewart et al., 2017). It is important to study the communication style of Gen $Y$ and Gen $Z$ because effective communication is directly correlated with organisational success (Hartman \& McCambridge, 2011). Hartman and McCambridge (2011) only wrote about the importance of equipping Gen $Y$ with communication skills of style-typing and style-flexing to develop their leadership acumen. They did not focus on Gen Z because one decade ago Gen Z had not entered the workplace. Incompatible communication styles that occur within a multigenerational workplace setting would potentially amplify the generational differences, and create conflict and miscommunication which affects the overall productivity of the organisation (Singh et al., 2020). The scant findings available on communication style are from studies focusing on leadership style, where communication is only an adjunct (see Ahmad \& Ibrahim, 2015; Soieb et al., 2015). As pointed out by McCroskey et al. (1998), there is an empirical paucity in terms of quantity and cohesiveness in the area of communication style research. Therefore, in view of the lack of research on the communication style of Gen Y and Gen Z, studies are needed to produce empirical findings that are potentially useful for increasing employee retention, bridging intergenerational differences in workplace communication and improve multigenerational workplace management.

The present study examined the communication style of Gen $Y$ and Gen Z in Malaysia. The objectives of the study focused on the general characteristics, study and work habits, and communication style.

\section{Theoretical framework of the study}

The theoretical framework of the study was adapted from Hartman and McCambridge (2011) because this is the most appropriate framework for researching communication style. They advocate the dual concepts of communication style-typing and style-flexing, which requires individuals to improve the fit between their communication style and their interactants, and this constitutes development of interpersonal communication skills to be effective communicators. According to Hartman and McCambridge (2011), style-typing is a technique for recognising one's own preferred communication style and those of their target group. Once the dominant communication styles have been identified, style-flexing follows. Style-flexing refers to the ability to adapt one's dominant style to the target group's styles to communicate on the same wavelength. People may use a mixture of styles, but the awareness of one's own communication styles and those of the target group is important to lower communication barriers.

Hartman and McCambridge (2011) proposed an assessment tool to identify the four main communication styles based on Mok (1975) which is underpinned by Jungian psychology and transactional analysis. As Hartman and McCambridge (2011) had made vast changes to Mok's communication style (sensor, thinker, intuition, feeler) to highlight the communication style angle, reference will not be made to Mok (1975). The following description is based on Hartman and McCambridge (2011).

The four communication styles (Analytical, Driver, Amiable, and Expressive) are based on two dimensions, that is, assertiveness and responsiveness. Assertive people feel a need to control situations, and they usually talk more than listen, and start discussions. On the other hand, responsive individuals are emotionally expressive, and they listen more than they talk. The level of assertiveness is determined by assessing pace (fast vs. slow), whereas the level of responsiveness is determined by assessing priority (task vs. relationship orientation). This gives rise to four quadrants in the profiling of an individual's communication style as shown in Figure 1, and explained as follows: 
(1) Expressive - high assertiveness, high responsiveness (fast pace of communication, relationship priority). The Expressive asks "how" questions to create alliances (e.g., How can we work with others to achieve our goals within the given time?).

(2) Driver - high assertiveness, low responsiveness (fast pace of communication, task priority). The driver asks "what" questions to get results from tasks (e.g., What is the purpose of your plan?).

(3) Amiable - low assertiveness, high responsiveness (slow pace of communication, relationship priority). The Amiable asks "who" questions to conform and cooperate (e.g., Who have you considered when making this plan? and What is their view?).

(4) Analytical - low assertiveness, low responsiveness (slow pace of communication, task priority). The Analytical asks "why" questions to work within the system, and are indecisive, uncommunicative and impersonal (e.g., Why do you do it that way and not this way).

Figure 1. Four categories of communication styles based on dimensions of assertiveness and responsiveness

High Responsiveness

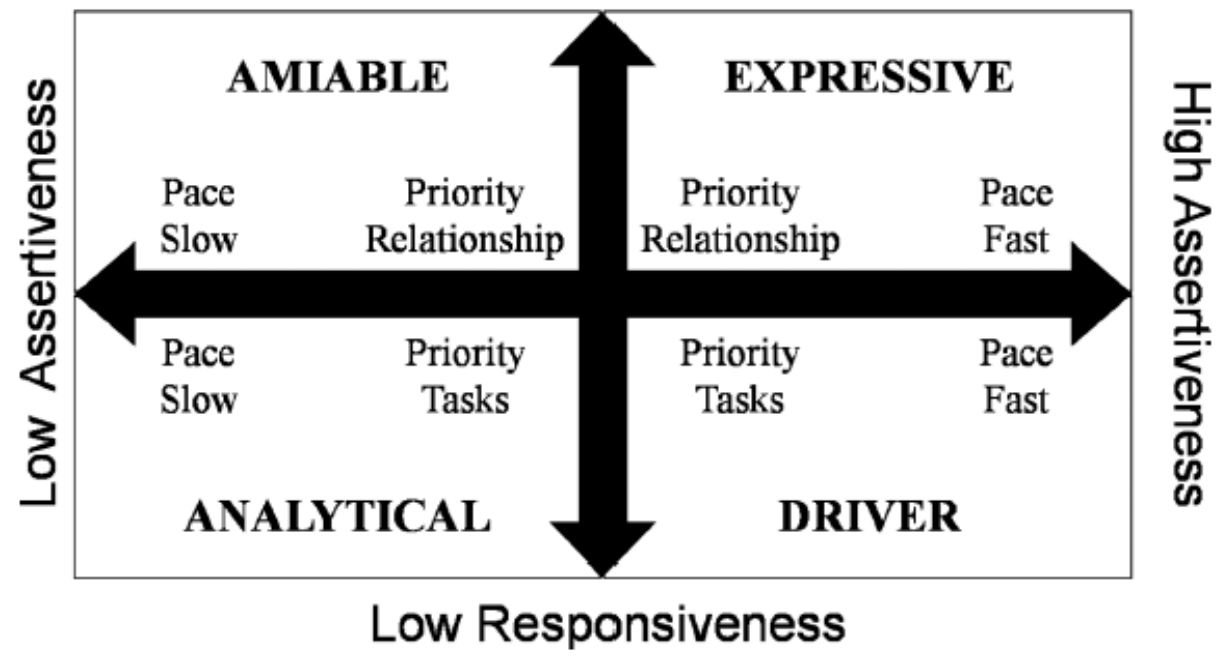

Source: Hartman \& McCambridge, 2011

Hartman and McCambridge's (2011) assessment tool comprised 67 items but only descriptions related to assertiveness and responsiveness dimensions and the communication pace and task versus relationship priority were used in the description above. The other items are not relevant as the purpose of this study is not to profile the individual participants as expressive, driver, amiable, and analytical communicators. An example of an excluded item is whether they liked Oprah Winfrey.

\section{Method}

A survey was conducted on youth in the Gen $Y$ and Gen $Z$ age range in Malaysia, that is, between 23 and 40. The participants were 311 youth (Gen Y, 68; Gen Z, 243). There were more female participants, but the ethnic composition reflects that of Malaysia which has $62.51 \%$ Malay (inclusive of indigenous), $20.56 \%$ Chinese, $6.18 \%$ Indian, and $10.75 \%$ others making up the $32,581,400$ population (Department of Statistics, Malaysia, 2020). A majority of the participants had at least Form 6, Matriculation or Diploma qualification, and $49.46 \%$ of the participants had a monthly income of less than RM2000 as $76.21 \%$ were students. However, their parents' monthly income was quite evenly spread, except that there were fewer with a combined income of above RM6000 per month. The large student population is expected because of the focus of the study on both Gen $Y$ (who were already working but some were pursuing postgraduate studies) and Gen Z (who were mostly still studying). 
Table 1 Percentages showing demographic information on participants $(N=311)$

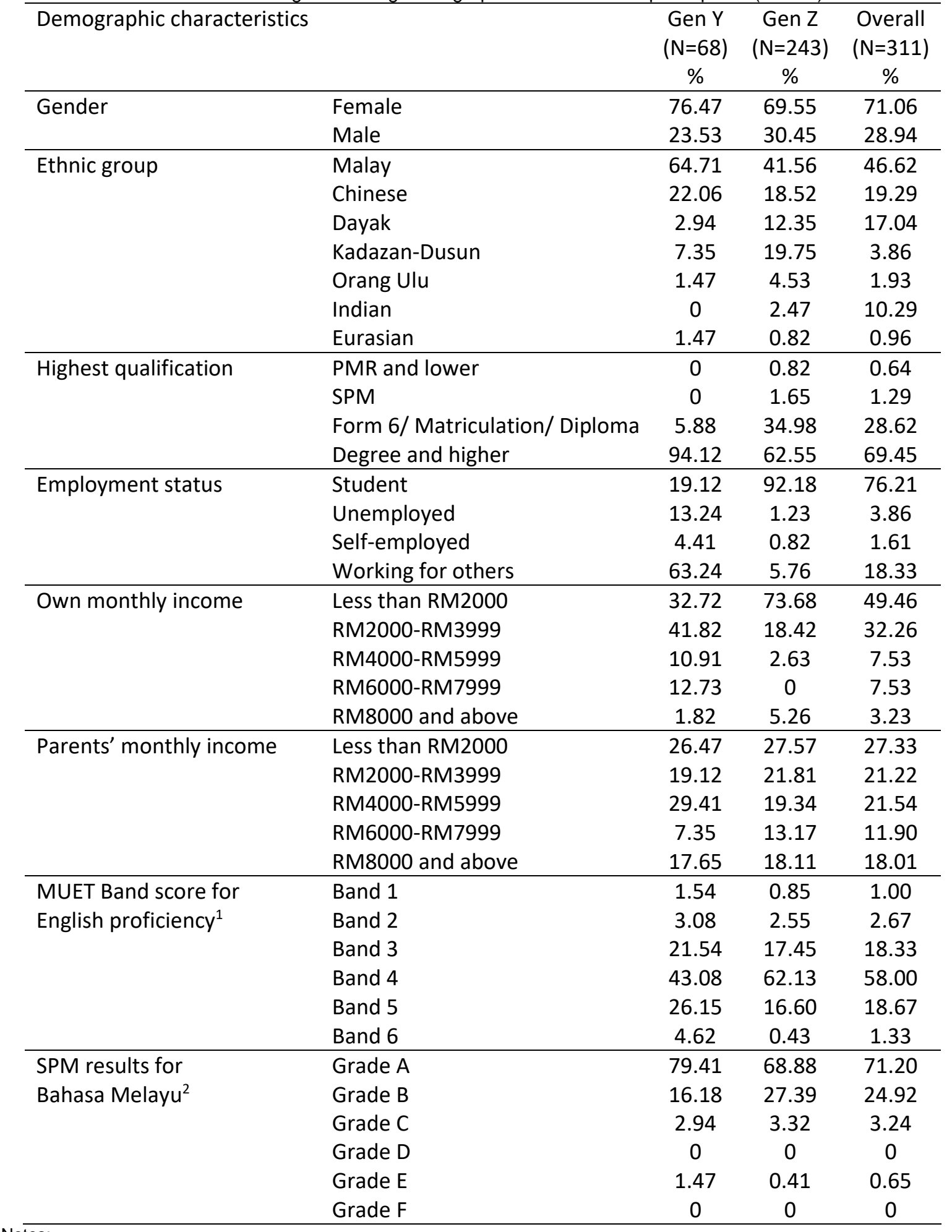

Notes:

Malaysian University English Test (MUET) tests students' proficiency in listening, speaking, reading and writing, and the scores are from Band 1 (lowest) to Band 6 (highest).

Sijil Pelajaran Malaysia (SPM) examination for the Bahasa Melayu subject includes both spoken and written skills, and the grades are from Grade A (highest) to Grace F (fail). 
The participants' proficiency in English and Malay were obtained because language proficiency influences communicative ability. Table 1 shows that the participants' Malay proficiency was good (71.20\% scored A), but their English proficiency was lacking (only $20.00 \%$ scored the top two bands of Bands 5 and 6 in MUET).

The questionnaire was developed from Hartman and McCambridge's (2011) description of Gen $Y$ communication styles (Appendix 1). The sections in the questionnaire were on demographic background, general characteristics of Gen Y (11 items), study and work habits (5 items), communication style (11 items). A five-point Likert scale from Strongly Disagree to Neither Disagree Nor Agree to Strongly Agree was used.

The questionnaire was designed in Google Form, and the purpose of the study, voluntary participation, and confidentiality of responses were explained. Youth in the Gen $\mathrm{Y}$ and Gen $\mathrm{Z}$ age groups were invited to fill in the questionnaire from 26 April 2020 to 11 May 2020. Out of 312 questionnaires received, one participant above 40 years old was eliminated, leaving 311 for the analysis.

The data were coded for analysis. Mean scores and standard deviations were computed. As the items used a five-point scale, the mid-point was three. To profile the participants according to the four communication styles (Hartman \& McCambridge, 2011) on the two dimensions (assertivenessresponsiveness, and task versus relationship priority), the mean scores were categorised as low (0-1.6), medium (1.7-3.3) and high (3.4-5.0). T-tests (threshold value of $p<0.05)$ were conducted to find out if there were differences between Gen $Y$ and Gen Z. T-tests were also conducted to determine if there were gender differences in characteristics, study and work habits, and communication styles. Additionally, Pearson correlation tests were run to determine if these variables co-vary with age and socio-economic status.

\section{Results}

\subsection{General characteristics of Gen $Y$ and Gen Z}

The t-tests showed that there were no significant differences between Gen $\mathrm{Y}$ and Gen $\mathrm{Z}$ participants in their characteristics at $95 \%$ confidence level.

Table 2 Mean scores showing characteristics of Gen $Y$ and Gen Z participants ( $N=311)$

\begin{tabular}{|c|c|c|c|c|c|}
\hline & Characteristics & & & $\begin{array}{c}\mathrm{Ge} \\
(\mathrm{N}=2\end{array}$ & \\
\hline & & Mean & SD & Mean & SD \\
\hline 1 & I like clear rules. & 4.47 & 0.66 & 4.45 & 0.73 \\
\hline 2 & I like to get encouragement from people around me. & 4.19 & 0.82 & 4.15 & 0.81 \\
\hline 3 & I like to talk with people face-to-face. & 4.06 & 0.83 & 4.06 & 0.98 \\
\hline 4 & I like people to listen to my opinions. & 3.96 & 0.65 & 3.94 & 0.85 \\
\hline 5 & I like to be praised. & 3.71 & 0.98 & 3.74 & 0.97 \\
\hline 6 & $\begin{array}{l}\text { When I communicate online, I like to use visuals to share my } \\
\text { ideas. }\end{array}$ & 3.63 & 0.99 & 3.37 & 0.94 \\
\hline 7 & I like to work in groups. & 3.49 & 0.92 & 3.48 & 0.91 \\
\hline 8 & I have better communication skills than my friends. & 3.17 & 0.85 & 3.17 & 0.90 \\
\hline 9 & I do not like to be criticised. & 3.02 & 0.96 & 3.01 & 1.01 \\
\hline 10 & I usually think negatively about things. & 3.01 & 1.09 & 3.01 & 1.16 \\
\hline 11 & I like my parents to make decisions for me. & 2.60 & 0.98 & 2.61 & 0.89 \\
\hline
\end{tabular}


Table 2 shows the characteristics of Gen Y and Gen Z participants. Both Gen Y and Gen Z agreed that they liked to work in groups. Contrary to popular belief, they did not like their parents to make decisions for them. In other words, they perceived themselves as having independent thinking.

The results in Table 2 showed that both Gen $Y$ and Gen $Z$ thrive on positive affirmation. They like to be praised (Gen $Y: M=3.71, S D=0.98$; Gen $Z: M=3.74, S D=0.97$ ), and people to listen to their opinions (Gen $Y: M=3.96, S D=0.65$; Gen $Z: M=3.94, S D=0.85$ ). They also liked to be encouraged by people around them (Gen Y: $M=4.19, S D=0.82$; Gen $Z: M=4.15, S D=0.81$ ). In this respect, they are considered to be high maintenance. There were mixed responses on whether they liked to be criticised (Gen $Y: M=3.02$, $S D=0.96$; Gen $Z: M=3.01, S D=1.01$ ), and whether they usually think negatively about things (Gen $Y$ : $M=3.01, S D=1.09$; Gen $Z: M=3.01, S D=1.16)$. The mean scores showed that Gen $Y$ and Gen $Z$ were similar, indicating that there is no generational difference in how they react to negativity. Tyler (2008) stated that they could become aggressive when criticised.

Both groups expressed strong opinions that they liked clear rules (Gen Y: $M=4.47, S D=0.66$; Gen Z: $M=4.45, S D=0.73$ ), suggesting that structure is important in their lives. This means that they do not like ambiguity and grey areas. In an organisation, rules and regulations have to be clearly spelt out, making the rights and obligations plain. This also means that they abhorred disregard for rules and preferential treatment.

Gen $Y$ and Gen $Z$ are said to be so immersed in the social media world that they cannot communicate well in face-to-face interactions. However, the results showed that they liked to talk with people face-toface (Gen Y: $M=4.06, S D=0.83$; Gen $Z: M=4.06, S D=0.98$ ), and considered themselves to have better communication skills than their friends ( $G e n Y: M=3.17, S D=0.85$; $G$ en $Z: M=3.17, S D=0.90$ ). When they communicate online, they liked to use visuals to share their ideas (Gen Y: $M=3.63, S D=0.99$; Gen Z: $M=3.37, S D=0.94)$. In the same way, they would also like information to be shared with them visually rather in the form of text, characteristics of visual learners rather than verbal learners.

\subsection{Study and work habits of Gen Y and Gen Z}

Table 3 shows results on the study and work habits of Gen $Y$ and Gen Z participants. The t-test results showed significant differences between the two groups on three out of five characteristics studied. Gen $Y$ and Gen $Z$ were significantly different in how well they can analyse information that they find from the Internet at $p=0.01$ (Gen $Y: M=4.07, S D=0.80$; Gen $Z, M=3.79, S D=0.79$ ). The two groups were also significantly different on whether they can handle a lot of work at one time at $p=0.03$ ( $G$ en $Y: M=3.31$, $S D=1.05 ; G e n Z: M=2.99, S D=0.99$ ). There was also a significant difference between Gen $Y$ and Gen $Z$ on whether they liked to get feedback on their work in the same day at $p=0.01$ (Gen $Y: M=3.56, S D=0.97$; Gen Z: $M=3.90, S D=0.95)$.

The value of the mean scores indicated that Gen $Y$ were better at analysing information, and handling a lot of work at one time. Here, some demographic information is used to interpret the results. A large percentage of Gen $Y(67.65 \%$, Table 1$)$ was already working, and therefore they developed their analytical skills as well as their ability to handle heavy workload. The mean values also showed that more Gen Z participants liked to get instantaneous feedback than Gen Y participants. Gen Y participants who were older, and have begun working, realise that they could not expect their supervisors and employers to give them immediate feedback on their work in the same day, but the Gen Z participants still had unrealistic expectations due to lack of working experience. The demographic information in Table 1 shows that only $6.58 \%$ of Gen Z participants were working at the time of the study. Most of them were students. Their teachers and lecturers may or may not give feedback according to their expectations, but what the results showed is that Gen $Y$ and Gen $Z$ are significantly different in their expectation of instantaneous feedback. 
Table 3 Mean scores showing how Gen $Y$ and Gen $Z$ participants handle work and studies ( $N=311)$ How Gen $Y$ and Gen $Z$ handle work and studies $\quad$ Gen $Y(N=68) \quad$ Gen Z (N=243) T-test

\begin{tabular}{|c|c|c|c|c|c|c|}
\hline & \multirow[t]{2}{*}{ How Gen Y and Gen Z handle work and studies } & \multicolumn{2}{|c|}{ Gen $Y(N=68)$} & \multicolumn{2}{|c|}{ Gen Z (N=243) } & \multirow{2}{*}{$\begin{array}{l}\text { T-test } \\
\text { results }\end{array}$} \\
\hline & & Mean & SD & Mean & SD & \\
\hline 1 & $\begin{array}{l}\text { I can analyse information that I find from the } \\
\text { Internet well. }\end{array}$ & 4.07 & 0.80 & 3.79 & 0.79 & $* p=0.01$ \\
\hline 2 & I like to get feedback on my work in the same day. & 3.56 & 0.97 & 3.90 & 0.95 & $* p=0.01$ \\
\hline 3 & I can handle a lot of work at one time. & 3.31 & 1.05 & 2.99 & .99 & $* p=0.03$ \\
\hline 4 & $\begin{array}{l}\text { I usually submit my work before the deadline (due } \\
\text { date). }\end{array}$ & 3.93 & 0.98 & 4.03 & 0.88 & \\
\hline 5 & $\begin{array}{l}\text { I can find information that I need for my projects } \\
\text { easily. }\end{array}$ & 3.76 & 0.93 & 3.61 & 0.88 & \\
\hline \multicolumn{7}{|c|}{$\begin{array}{l}\text { Notes: } \\
\text { Items were on a five-point Likert scale from Strongly Disagree to Strongly Agree, and the mid-point is three. } \\
\text { *Significantly different at } p<0.01\end{array}$} \\
\hline \multicolumn{7}{|c|}{$\begin{array}{l}\text { The two groups were similar on two other aspects studied. They could find information that the } \\
\text { eded for their projects easily. Being the technology-savvy generations, they did not have problem } \\
\text { arching for required information on the Internet. However, after they had obtained the information } \\
n \mathrm{Y} \text { was better at processing the information than Gen } Z \text {. Their analytical capability differed; probabl } \\
\text { e to work experience and age effects. Both Gen } Y \text { and Gen } Z \text { were similar in reporting that they usual } \\
\text { omitted their work on time. They also felt that they were punctual in meeting academic or wor } \\
\text { adlines. The results reported earlier showed that Gen } Z \text { was not as good as Gen } Y \text { in handling a lot } \\
\text { rk at one time. This is an indication that if Gen } Z \text { were overwhelmed with assignments and project } \\
\text { ey might not be able to meet deadlines. Gen } Y \text { on the other hand was probably trained by their wor } \\
\text { vironment to meet project deadlines. These results are from the perspective of Gen } Y \text { and Gen } Z \text {, bu }\end{array}$} \\
\hline
\end{tabular}

\subsection{Communication style of Gen Y and Gen Z}

Table 4 shows the communication style of Gen $Y$ and Gen $Z$ participants. The t-test results showed significant differences for two out of 11 characteristics examined.

Gen $Y$ and Gen $Z$ were similar in their style-typing, meaning they are aware of their own communication style. They often compared their style of communicating with others. Table 4 shows that there were mixed responses on whether they communicated in the same way as their peers, in that Gen $Y(M=3.13)$ marginally agreed with this statement while $G e n Z$ marginally disagreed $(M=2.94)$. The mixed responses are expected because of individual differences in communication styles. Here, a reference to the earlier set of results is needed. Table 2 results showed that both groups were confident of their own communicative ability. Both groups expressed slight agreement that their communication style was better than their peers' ( $M=3.17$ for both Gen $Y$ and Gen $Z$ ). The results indicated that they have awareness of communication styles in order to report whether they have better communication style than their friends.

Gen $Y$ and Gen $Z$ participants were significantly different in style-flexing practices, that is, ability to adapt their style to their interactants' styles for more effective communication. Table 4 shows that the two groups differed significantly in their information-focus when they prepared powerpoint slides for oral presentation at $p=0.01$ (Gen $Y: M=4.31, S D=0.70$; Gen $Z: M=4.20, S D=0.75$ ). The mean values indicated that Gen $Y$ participants were more likely to focus on the information they wanted to present, while the Gen Z participants were more likely to consider the needs of their audience and tailor their slides to the target group. According to Hartman and McCambridge (2011), an information focus signifies a self-focus, as opposed to an audience-focus. It seems that Gen Y may be more self-focused, whereas 
Gen Z may be more other-focused. However, the differences between the two groups on the peoplefocus in their preparation of powerpoint slides for oral presentations were not big enough to be significant.

Table 4 Mean scores showing the communication style of Gen $Y$ and Gen $Z$ participants (N=311)

\begin{tabular}{|c|c|c|c|c|c|c|c|}
\hline Constructs & & Questionnaire items & & & & & $\begin{array}{l}\text { T-test } \\
\text { results }\end{array}$ \\
\hline Awareness of commu & icat & on styles & Mean & SD & Mean & SD & \\
\hline $\begin{array}{l}\text { Style-typing } \\
\text { (knowing own style) }\end{array}$ & 1 & $\begin{array}{l}\text { I often compare my style of } \\
\text { communicating with others. }\end{array}$ & 3.60 & 1.15 & 3.49 & 1.11 & \\
\hline & 2 & $\begin{array}{l}\text { I communicate in the same way } \\
\text { as others. }\end{array}$ & 3.13 & 0.90 & 2.94 & 0.83 & \\
\hline $\begin{array}{l}\text { Style-flexing } \\
\text { (information versus } \\
\text { audience focus) }\end{array}$ & 3 & $\begin{array}{l}\text { When I prepare powerpoint } \\
\text { slides for oral presentation, I } \\
\text { focus on the information I want } \\
\text { to present. }\end{array}$ & 4.31 & 0.70 & 4.20 & 0.75 & $* p=0.01$ \\
\hline & 4 & $\begin{array}{l}\text { When I prepare powerpoint } \\
\text { slides for oral presentation, I } \\
\text { make them to suit my audience } \\
\text { (people listening to me). }\end{array}$ & 4.24 & 0.79 & 3.95 & 0.83 & \\
\hline Types of communicati & on & & & & & & \\
\hline $\begin{array}{l}\text { Assertiveness versus } \\
\text { responsiveness }\end{array}$ & 5 & $\begin{array}{l}\text { When we meet for projects, I } \\
\text { usually start the discussion. }\end{array}$ & 3.52 & 1.01 & 3.42 & 1.02 & \\
\hline & 6 & I talk more than I listen. & 2.46 & 1.06 & 2.76 & 1.09 & $* p=0.04$ \\
\hline & 7 & $\begin{array}{l}\text { When I talk, I need to express } \\
\text { my feelings. }\end{array}$ & $3.16^{R}$ & 1.13 & $3.25^{\mathrm{R}}$ & 1.06 & \\
\hline & & Average Assertiveness Score & 2.60 & & 2.64 & & \\
\hline $\begin{array}{l}\text { Task versus } \\
\text { relationship priority } \\
\text { in task completion }\end{array}$ & 8 & $\begin{array}{l}\text { When we do projects, I usually } \\
\text { push members to get the job } \\
\text { done. }\end{array}$ & 3.38 & 1.07 & 3.39 & 1.04 & \\
\hline & 9 & $\begin{array}{l}\text { When we do projects, I usually } \\
\text { want to know what the } \\
\text { members think. }^{\text {R }}\end{array}$ & $4.24^{\mathrm{R}}$ & 0.71 & $4.26^{\mathrm{R}}$ & 0.74 & \\
\hline & & Average Task Priority Score & 2.07 & & 2.06 & & \\
\hline $\begin{array}{l}\text { Pace of } \\
\text { communication }\end{array}$ & 10 & $\begin{array}{l}\text { When I am given work to do, I } \\
\text { usually finish it quickly. }\end{array}$ & 3.31 & 1.03 & 3.36 & 0.94 & \\
\hline & 11 & $\begin{array}{l}\text { When I am given work to do, I } \\
\text { usually think a lot during each } \\
\text { step and do it slowly. }{ }^{R}\end{array}$ & $3.59^{R}$ & 0.90 & $3.71^{R}$ & 0.94 & \\
\hline & & $\begin{array}{r}\text { Average Fast-Paced } \\
\text { Communication }\end{array}$ & 2.36 & & 2.60 & & \\
\hline
\end{tabular}

Notes:

Items were on a five-point Likert scale from Strongly Disagree to Strongly Agree, and the mid-point is three.

*Significant difference at $p<0.01$

Means were reversed for the calculation of the average mean score so that bigger numbers reflect assertiveness, task priority in task completion, and fast-paced communication accordingly

Based on these results, the participants were better at style-flexing than style-typing. However, if they are not accurate in recognising the type of communication style, the modification they make in their oral presentations may not be on target, and they still would not be able to overcome 
communication barriers. To help the Gen $\mathrm{Y}$ and Gen $\mathrm{Z}$ to become better communicators, they need to be trained to recognise communication styles.

Next, the results on the four communication types are described, focussing on the assertivenessresponsiveness, and task-relationship priority dimensions. Table 4 shows that the Gen $Y$ and Gen Z were significantly different on one out of three aspects of the assertiveness-responsiveness dimension examined. There were significant differences between the two groups on whether they talked more than they listened at $p=0.04$ ( $G e n Y, M=2.46, S D=1.06$; $G e n Z, M=2.76, S D=1.09$ ). Both groups listened more than they talked, but the mean values indicated that Gen $Y$ participants expressed greater disagreement with the statement, that is, Gen Y listened more than Gen Z. According to Hartman and McCambridge (2011), talking more than listening reflects assertiveness whereas listening more is a responsive communication style. Both groups were responsive, but Gen $Y$ talked less than Gen Z. Gen Y and Gen Z participants were similar on the other two aspects of the assertiveness-responsiveness dimension. When they met for projects, they usually took the lead and started the discussion. This is a characteristic of assertive behaviour, and reflects a need to be in control. They were also emotionally expressive, characteristic of a responsive behaviour (Hartman \& McCambridge, 2011). Taken together, both groups reported both assertive and responsive behaviour in communication.

As for task versus people priority in task completion, the mean values in Table 4 showed that both groups were similar in giving more priority to people than to task in getting the job done. They reported that when they did projects, they usually wanted to know what the members thought, and minimally pushed their members to get the job done. By giving more priority to people, they showed that they valued their members' views and ideas. However, when there are conflicting opinions and they are unable to push group members, the timely and good completion of the job may be at stake.

The pace of communication of both groups can be characterised as somewhat slow rather than fast. They minimally agreed that they finished given work quickly, but they reported stronger agreement with the statement that they usually thought a lot during each step and did the work slowly. A slow pace of work is associated with responsiveness, and not assertiveness.

The t-tests showed that were no significant differences in the communication style of Gen $Y$ and Gen $Z$ at $95 \%$ confidence level (see Table 4). The subsequent statistical tests were conducted for the 311 participants as a group since the two generational cohorts were similar in their communication style. The t-tests showed that there were also no significant gender differences in the communication style of the participants. The Pearson correlation tests showed that there was no relationship between the participants' communication style and their parents' income (indicative of socio-economic status). These results suggest that differences in the communication style of Gen $Y$ and Gen $Z$ were not due to their demographic background, but their generational cohort.

Finally, average assertiveness, task priority, and fast-paced communication scores were computed, as shown in Table 4. Both Gen $Y$ and Gen $Z$ can be characterised as having low assertiveness (Gen $Y$, $M=2.60$; Gen $Z, M=2.64$ ), a relationship-priority in task completion ( $G e n Y, M=2.07$; $G e n Z, M=2.06$ ), and a slow-paced communication (Gen Y, M=2.36: Gen Z, M=2.60). In Hartman and McCambridge's (2011) framework of communication styles, both groups of participants can be described as amiable communicators (see Figure 1). They are more likely to cooperate during communication, and to conform to group expectations and norms. They ask the "who" questions because they prioritise the opinions of others, and are inclusive in their decision-making.

\section{Discussion}

The study on Gen $Y$ and Gen $Z$ showed that they are similar in their general characteristics, which include preferences for group-work, affirmation, clear rules, and for their opinions to be valued. They 
like face-to-face communication, and using visuals for online communication. There are significant differences in some of their study and work habits, that is, the Gen $Y$ are better than Gen $Z$ at analysing information obtained from the Internet, handling a lot of work at one time. Both generational cohorts expect frequent feedback, but Gen $Z$ expect more instantaneous feedback than Gen Y. As for communication style, both Gen $Y$ and Gen $Z$ are amiable communicators who are low on assertiveness, prioritise relationship over task in task completion, and have a slow-paced communication style. The results showed that Gen $Y$ and Gen $Z$ have some level of style-typing ability, that is, knowing their own communication style by making comparisons with peers. More of them practise style-flexing, as in fitting their communication to the target group to engage with them, but Gen $Y$ have a stronger informationfocus in their oral presentations. Their demographic background (gender, ethnic group, socio-economic status) do not influence their communication style, indicating the stronger influence of their generational cohort.

This study offers a description of communication styles of Gen $Y$ and Gen $Z$ in Malaysia, which is previously under-researched. The extant findings on the generational cohorts have concentrated on their traits (e.g., Seemiller \& Grace, 2016; Smith \& Nichols, 2015; Torocsik et al., 2014) and study behaviours (both Gen Y and Gen Z). Research on work behaviours are mostly on Gen Y (e.g., Hemdi et al., 2018; Jiří, 2016; Kraus, 2017) because Gen Z are only beginning to enter the workforce at this point in time. We have intentionally omitted a detailed investigation of their technology use as their technology-savvy behaviour is already established (e.g., Said et al., 2020), and they are known to be able to use of technology to multitask (Schwieger \& Ladwig, 2018) and to obtain information through online channels (Rickes, 2016; Turner, 2015). As for communication, other researchers have already profiled Gen Y's preference for open, inclusive, and frequent communication at work (Abdul Malek \& Jaguli, 2018; Soeib et al., 2015), and their need for frequent feedback (Stewart et al., 2017; Yeap et al., 2018). As for Gen Z, studies have also shown Gen Z's willingness to share information (Bencsik et al., 2016), particularly using visuals and emojis and acronyms (Rickes, 2016). To these findings, we add new findings on the awareness of Gen $Y$ and Gen $Z$ on the importance of style-flexing, that is, modifying their dominant communication style to suit the target group's styles. The finding suggests that Gen $Y$ and Gen $Z$ employees may be able to adapt their communication style to those of the Gen X and Baby Boomers who occupy higher hierarchical positions in the organisation. However, the findings in this study also indicated that the Gen $Y$ and Gen $Z$ may not have the ability to fit their communication styles to the group because of their limited style-typing skills. They may lack knowledge of communication styles to make useful assessments of where they stand in terms of their communication skills. However, further research using simulated situations is needed to verify the findings on the limited style-typing ability of Gen $Y$ and Gen $Z$ which are based on their perceptions. If weak style-typing and style-flexing abilities are prevalent across Gen $Y$ and Gen Z, then they will benefit from training sessions on the dual concepts of communication style-typing and style-flexing, using materials such as Hartman and McCambridge's (2011) communication style inventory, which was used to develop the communication style questionnaire in the present study. With a better fit between the communication styles of multigenerational individuals either in academic institutions or the workplace, communication barriers will be lowered.

The study had also identified the Gen $Y$ and Gen $Z$ respondents as having an amiable communication style, that is, they are more responsive instead of assertive, prioritise relationship orientation over task, and have a slow pace in task completion. Their inclination to conform and cooperate means that they may not be able to handle conflicts, which are often inevitable in the workplace. The findings concur with Sriprom et al. (2019) who found that Thai Gen Z university students are high on the agreeableness trait of personality. They have difficulty working alone and making decisions because they are relationship-oriented. While Gen $Y$ and Gen $Z$ may like frequent feedback from their superiors 
(Campiere, 2019; Stewart et al., 2017), they may not take well to criticisms. This, too, is unavoidable in the workplace as shown by Yeap et al. (2018). Over half (52.31\%) of the Malaysian polytechnic graduates surveyed received positive comments all the time but $42.57 \%$ reported receiving criticisms frequently. An implication of the study is for employers to make their work expectations clear to Gen $\mathrm{Y}$ and Gen Z employees. Otherwise, task completion is compromised, leading to poor productivity. As amiable communicators, Gen $Y$ and Gen $Z$ value the opinions of others in decisions and plans. In the same way, they expect their views to be considered. Researchers (Abdul Malek \& Jaguli, 2018; Soeib et al., 2015) have found the importance of open, inclusive and frequent communication, but a potent area to investigate is whether inclusive communication and similar communication styles of older generational cohorts can increase job satisfaction and retention of talents.

\section{References}

1. Abdul Malek, M. M. A., \& Jaguli, A. R. (2018). Generational differences in workplace communication: Perspectives of female leaders and their direct reports in Malaysia. Journal of Asian Pacific Communication, 28(1), 129-150.

2. Ahmad, H., \& Ibrahim, B. (2015). Leadership and the characteristic of different generational cohort towards job satisfaction. Procedia-Social and Behavioral Sciences, 204(2015), 14-18. 10.1016/j.sbspro.2015.08.104

3. Andi, H.K. (2018). Leadership Styles Preference among Millennials Workforce. Malaysian Journal of Youth Studies, 19, 114-134.

4. Bencsik, A., Horváth-Csikós, G., \& Juhász, T. (2016). Y and Z generations at workplaces. Journal of Competitiveness, 8(3), 90-106.

5. Campiere, A. (2019, February 14). How Gen Z communicates at work. PCMA. https://www.pcma.org/how-generation-z-communicates-work/

6. Department of Statistics, Malaysia. (2020). Quick population statistics. http://pqi.stats.gov.my/result.php?token=5807c9b9b54242f7ba3ce87bf73fc229

7. Dimock, M. (2019, January 17). Defining generations: Where millennials end and Generation $Z$ begins. Pew Research Center. https://www.pewresearch.org/fact-tank/2019/01/17/where-millennials-endand-generation-z-begins/

8. Hartman, J. L., \& McCambridge, J. (2011). Optimizing millennials' communication styles. Business Communication Quarterly, 74(1), 22-44.

9. Hemdi, M. A., Buang, F. H., \& Saidmamatov, O. (2018). Investigating the role of motivational factors and job-hopping attitudes on turnover intentions of Gen $Y$ hotel employees. International Journal of Academic Research in Business and Social Sciences, 8(15) Special Issue, 1-13.

10.Holt, S., Marques, J., \& Way, D. (2012). Bracing for the millennial workforce: Looking for ways to Inspire Generation Y. Journal of Leadership, Accountability and Ethics, 9(6), 81-93

11.Islam, M. A., Cheong, T. W., Yusuf, D. H. M., \& Desa, H. (2011). A study on Generation Y behaviours at workplace in Penang. Australian Journal of Basic and Applied Sciences, 5(11), 1802-1812.

12.Jalil, S. W., Achan, P., Mojolou, D. N., \& Rozaimie, A. (2015). Individual characteristics and job performance: generation Y at SMEs in Malaysia. Procedia-Social and Behavioral Sciences, 170, 137145.

13.Jiří, B. (2016). The employees of Baby Boomers generation, Generation X, Generation $Y$ and Generation $\mathrm{Z}$ in selected Czech corporations as conceivers of development and competitiveness in their corporation. Journal of Competitiveness, 8(4), 105-123. 
14.King, E., Finkelstein, L., Thomas, C., \& Corrington, A. (2019, August 1). Generational differences at work are small. Thinking they're big affects our behavior. Harvard Business Review. https://hbr.org/2019/08/generational-differences-at-work-are-small-thinking-theyre-big-affects-ourbehavior

15.Koh, Y. H. (2018). Factors affecting the retention of Generation $Y$ workers in food industry (Unpublished Master dissertation). Universiti Tunku Abdul Rahman Malaysia.

16.Kraus, M. (2017). Comparing Generation $X$ and Generation $Y$ on their preferred emotional leadership style. Journal of Applied Leadership and Management, 5, 62-75.

17.McCroskey, J. C., Daly, J. A., Martin, M. M., \& Beatty, M. J. (1998). Communication and personality: Trait perspectives. Cresskill, NJ: Hampton Press, Inc.

18.Mok, P. (1975). Interpretation manual for communicating styles and technology. Richardson, TX: Training Associates Press.

19.Myers, K. K., \& Sadaghiani, K. (2010). Millennials in the workplace: A communication perspective on millennials' organizational relationships and performance. Journal of Business and Psychology, 25(2), 225-238.

20.Naim, M. F., \& Lenka, U. (2017). Mentoring, social media, and Gen Y employees' intention to stay: towards a conceptual model. International Journal of Business and Systems Research, 11(1-2), 28-41.

21.Raslie, H., Pit, S., \& Ting, S. H. (2016). Millennials' expectations of life at the university and the workplace: A Malaysian perspective. International Journal of Education, 8(3), 71-84.

22.Rickes, P. C. (2016). Generations in flux: How Gen Z will continue to transform higher education space. Planning for Higher Education, 44(4), 1-21.

23.Said, R. A., Mohd Rashid, A. A., \& Othman, M. A. (2020). Generation Z for job employment: Characteristic and expectation. International Journal of Academic Research in Business and Social Sciences, 10(3), 570-575.

24.Schwieger, D., \& Ladwig, C. (2018). Reaching and retaining the next generation: Adapting to the expectations of Gen Z in the classroom. Information Systems Education Journal, 16(3), 45-54.

25.Seemiller, C., \& Grace, M. (2016). Generation Z goes to college. New Jersey: John Wiley \& Sons.

26.Singh, A. P., \& Dangmei, J. (2016). Understanding the generation Z: the future workforce. South-Asian Journal of Multidisciplinary Studies, 3(3), 1-5.

27.Smith, T. J., \& Nichols, T. (2015). Understanding the millennial generation. The Journal of Business Diversity, 15(1), 39, 1-5.

28.Soieb, A. Z. M., Othman, J., \& D'Silva, J. L. (2015). Mediating influence of collaboration on the relationship between leadership styles and employee engagement among generation $Y$ officials in Malaysian public sector. Journal of Applied Sciences, 15(1), 7-31.

29.Sriprom, C., Rungswang, A., Sukwitthayakul, C., \& Chansri, N. (2019). Personality traits of Thai Gen Z undergraduates: Challenges in the EFL classroom? PASAA: Journal of Language Teaching and Learning in Thailand, 57, 165-190.

30.Stewart, J. S., Oliver, E. G., Cravens, K. S., \& Oishi, S. (2017). Managing millennials: Embracing generational differences. Business Horizons, 60(1), 45-54.

31.Törőcsik, M., Szúcs, K., \& Kehl, D. (2014). How generations think: research on generation z. Acta universitatis Sapientiae, Communicatio, 1(1), 23-45.

32.Turner, A. (2015). Generation Z: Technology and social interest. The Journal of Individual Psychology, 71(2), 103-113. 
33.Tyler, K. (2008, January 1). Generation gaps: Millennials may be out of touch with the basics of workplace behavior. HR Magazine, 69-72.

34.Yeap, L. H., Ting, S. H., \& Ooi, K. B. (2018). Malaysian Gen Y's work behaviours and Attitudes towards job retention and career advancement. Journal of Advanced Research in Social and Behavioural Sciences, 12(1), 64-76.

Appendix 1: Questionnaire for Gen $Y$ and Gen $Z$ characteristics and communication style

\section{GEN Y AND GEN Z COMMUNICATION STYLE}

Section 1: About you

1. Your gender

[ ] Female

[ ] Male

2. Your age:

3. Your ethnicity:

[ ] Malay

[ ] Chinese

[ ] Dayak

[ ] Kadazan-Dusun

[ ] Orang Ulu

[ ] Indian

[ ] Eurasian

4. Your education background (choose one)

[ ] PMR or lower

[ ] SPM/ O Level

[ ] STPM/ A Level

5. You are currently (select one)

[ ] A student

[ ] Working for someone else

[ ] Self-employed

[ ] Unemployed

6. If you are working, state your income per month (skip this question if you are a student or unemployed)

[ ] Less than RM 2000

[ ] RM $2000-$ RM 3999

[ ] RM $4000-$ RM 5999

[ ] RM $6000-$ RM 7999

[ ] RM 8000 and above 
7. Your parents/guardian's income per month

[ ] Less than RM 2000

[ ] RM 2000 - RM 3999

[ ] RM 4000 - RM 5999

[ ] RM 6000 - RM 7999

[ ] RM 8000 and above

8. Your MUET Band score for English Proficiency

[ ] Band 1

[ ] Band 2

[ ] Band 3

[ ] Band 4

[ ] Band 5

[ ] Band 6

9. Your SPM results for Bahasa Melayu

[ ] Grade $A(A+/ A / A-)$

[ ] Grade $B(B+/ B)$

[ ] Grade $C(C+/ C)$

[ ] Grade D

[ ] Grade E

[ ] Grade G

Section 2: Your characteristics (select one only)

\begin{tabular}{cl}
\hline & [ ] Strongly disagree \\
1. I like to work in groups. & [ ] Neither disagree nor agree \\
& [ ] Agree \\
& [ ] Strongly agree \\
\hline 2. I like my parents to make decisions for me. & [ ] Strongly disagree \\
& [ ] Disagree \\
& [ ] Neither disagree nor agree \\
& [ ] Agree \\
& [ ] Strongly agree \\
3. I like to be praised. & [ ] Strongly disagree \\
& [ ] Disagree \\
& [ ] Neither disagree nor agree \\
& [ ] Agree \\
& [ ] Strongly agree \\
4. I like people to listen to my opinions. & [ ] Strongly disagree \\
& [ ] Disagree \\
& [ ] Neither disagree nor agree \\
& [ ] Agree \\
& [ ] Strongly agree
\end{tabular}


5. I do not like to be criticised.

[ ] Strongly disagree

[ ] Disagree

[ ] Neither disagree nor agree

[ ] Agree

[ ] Strongly agree

[ ] Strongly disagree

6. I like clear rules.

[ ] Disagree

[ ] Neither disagree nor agree

[ ] Agree

[ ] Strongly agree

\section{[ ] Strongly disagree}

7. I like to talk with people face-to-face.

[ ] Disagree

[ ] Neither disagree nor agree

[ ] Agree

[ ] Strongly agree

\section{[ ] Strongly disagree}

8. I like to get encouragement from the people [ ] Disagree around me.

[ ] Neither disagree nor agree

[ ] Agree

[ ] Strongly agree

\section{[ ] Strongly disagree}

9. I usually think negatively about things.

[ ] Disagree

[ ] Neither disagree nor agree

[ ] Agree

[ ] Strongly agree

Section 3: Your communication style

\begin{tabular}{ll}
\hline 1. I have better communication skills than my & [ ] Strongly disagree \\
friends. & [ ] Disagree \\
& [ ] Neither disagree nor agree \\
& [ ] Agree \\
& [ ] Strongly agree \\
\hline [ ] Strongly disagree \\
2. I often compare my style of communicating with & [ ] Disagree \\
[ others. & [ ] Neither disagree nor agree \\
& [ ] Strongly agree \\
& [ ] Strongly disagree \\
& [ ] Disagree \\
3. I communicate in the same way as others. & [ ] Agree \\
& [ ] Strongly agree
\end{tabular}


4. When I prepare powerpoint slides for oral presentation, I focus on the information I want to present.

[ ] Strongly disagree

[ ] Disagree

[ ] Neither disagree nor agree

[ ] Agree

[ ] Strongly agree

[ ] Strongly disagree

5. When I prepare powerpoint slides for oral

[ ] Disagree presentation, I make them to suit my audience (people listening to me).

[ ] Neither disagree nor agree

[ ] Agree

[ ] Strongly agree

\section{[ ] Strongly disagree}

6. When we meet for projects, I usually start the

[ ] Disagree discussion.

[ ] Neither disagree nor agree

[ ] Agree

[ ] Strongly agree

[ ] Strongly disagree

[ ] Disagree

7. I talk more than I listen.

[ ] Neither disagree nor agree

[ ] Agree

[ ] Strongly agree

[ ] Strongly disagree

8. When I talk, I need to express my feelings.

[ ] Disagree

[ ] Neither disagree nor agree

[ ] Agree

[ ] Strongly agree

[ ] Strongly disagree

9. When we do projects, I usually push members to

[ ] Disagree get the job done.

[ ] Neither disagree nor agree

[ ] Agree

[ ] Strongly agree

[ ] Strongly disagree

10. When we do projects, I usually want to know what the members think.

[ ] Disagree

[ ] Neither disagree nor agree

[ ] Agree

[ ] Strongly agree

[ ] Strongly disagree

11. When I am given work to do, I usually finish it

[ ] Disagree quickly.

[ ] Neither disagree nor agree

[ ] Agree

[ ] Strongly agree

[ ] Strongly disagree

12. When I am given work to do, I usually think a lot

[ ] Disagree during each step and do it slowly.

[ ] Neither disagree nor agree

[ ] Agree

[ ] Strongly agree 
Section 4: Your study and working style

\begin{tabular}{|c|c|}
\hline $\begin{array}{l}\text { 1. I can find information that I need for my projects } \\
\text { easily. }\end{array}$ & $\begin{array}{l}\text { [ ] Strongly disagree } \\
\text { [ ] Disagree } \\
\text { [ ] Neither disagree nor agree } \\
\text { [ ] Agree } \\
\text { [ ] Strongly agree }\end{array}$ \\
\hline $\begin{array}{l}\text { 2. I can analyse information that I find from the } \\
\text { Internet well. }\end{array}$ & $\begin{array}{l}\text { [ ] Strongly disagree } \\
\text { [ ] Disagree } \\
\text { [ ] Neither disagree nor agree } \\
\text { [ ] Agree } \\
\text { [ ] Strongly agree }\end{array}$ \\
\hline 3. I can handle a lot of work at one time. & $\begin{array}{l}\text { [ ] Strongly disagree } \\
\text { [ ] Disagree } \\
\text { [ ] Neither disagree nor agree } \\
\text { [ ] Agree } \\
\text { [ ] Strongly agree }\end{array}$ \\
\hline $\begin{array}{l}\text { 4. I usually submit my work before the deadline } \\
\text { (due date). }\end{array}$ & $\begin{array}{l}\text { [ ] Strongly disagree } \\
\text { [ ] Disagree } \\
\text { [ ] Neither disagree nor agree } \\
\text { [ ] Agree } \\
\text { [ ] Strongly agree }\end{array}$ \\
\hline 5. I like to get feedback on my work in the same day. & $\begin{array}{l}\text { [ ] Strongly disagree } \\
\text { [ ] Disagree } \\
\text { [ ] Neither disagree nor agree } \\
\text { [ ] Agree } \\
\text { [ ] Strongly agree }\end{array}$ \\
\hline
\end{tabular}

